К.В. Циганков ${ }^{1}$ В.О. Логвиненко ${ }^{2}$, І.В. Кужевський', В.М. Павленко ${ }^{1}$ 'Комунальне некомерційне підприємство «Міська клінічна лікарня № 4» Дніпровської міської ради, Дніпро ${ }^{2}$ Комунальне некомерційне підприємство «Міська клінічна лікарня № 21 імені професора Є.Г. Попкової» Дніпровської міської ради, Дніпро

\title{
Ураження порожньої кишки як можлива причина розвитку гострого респіраторного дистрес-синдрому при COVID-19
}

Актуальним і маловивченим питанням при COVID-19 є морфологічна картина патологічних змін шлунково-кишкового тракту. На підставі патоморфологічного дослідження матеріалу від чотирьох померлих пацієнтів iз COVID-19 і аналізу даних літератури зроблено висновок, що важливим чинником розвитку тяжкої та вкрай тяжкої форми COVID-19 може бути ураження порожньої кишки у поєднанні із захворюваннями, які спричиняють виникнення портопульмональної гіпертензії.

Ключові слова: COVID-19, шлунково-кишковий тракт, порожня кишка, інтрамуральний нервовий ганглій, портопульмональна гіпертензія.

\section{Вступ}

Згідно з визначенням Всесвітньої організації охорони здоров'я, коронавірусна інфекція 2019 р. (COVID-19) є інфекцією дихальних шляхів, що викликається новим коронавірусом SARSCoV-2, який вперше виявлений у місті Ухань (Китай) угрудні 2019 р. У більшості людей перебіг захворювання відбувається в легкій формі без ускладнень, проте у $14 \%$ воно переходить у тяжку форму, що вимагає госпіталізації та кисневої підтримки, а 5\% пацієнтів потребують переведення у відділення реанімації (WHO, 2020).

Особи з хронічними захворюваннями мають високий ризик розвитку тяжкої форми COVID-19. Персистуючий запальний статус у цих пацієнтів діє як важливий тригер для каскаду коагуляції, що призводить до розвитку дисемінованої внутрішньосудинної коагуляції. Вважають, що внаслідок прямої дії вірусу відбувається пошкодження ендотелію судин легень і периферичних судин, що також є важливим індуктором гіперкоагуляції, як і агресивний імунний відгук. Характерним для тяжкої форми COVID-19 є розвиток мікроангіопатії у вигляді деструктивно-продуктивного тромбоваскуліту та гіперкоагуляційного синдрому. При аутопсії померлих від COVID-19 основні патологічні зміни виявляють у легенях у вигляді дифузного альвеолярного пошкодження, морфологічно схожого з картиною «шокових легень» при гострому респіраторному дистрес-синдромі (ГРДС), але нерідко відзначають ураження водночас з легенями інших органів, яке за тяжкістю може превалювати над легеневою патологією, а також сепсис і септичний (інфекційно-токсичний) шок при приєднанні бактерійної інфекції. Шок неясного патогенезу та клінічно схожий із септичним відзначали й без бактерійної коінфекції (Зайратьянц О.В. и соавт., 2020).

Патологія з боку шлунково-кишкового тракту (ШКТ) становить значний інтерес у зв'язку з повідомленнями про кишкові клінічні прояви COVID-19. Діарея була поширеним симптомом коронавірусної інфекції під час спалаху у 2003 р. Так, в одному з досліджень відзначено, що діарея була наявна у $73 \%$ пацієнтів із SARS (Peiris J.S. et al., 2003). Симптоми з боку ШКТ можуть виявлятися вже на ранніх стадіях COVID-19, і такі прояви, як нудота, блювання та діарея, можуть бути одними з перших симптомів, а в деяких випадках - навіть з'явитися раніше, ніж лихоманка чи респіраторні симптоми (Chan J.F. etal., 2020). Цікаво, що для COVID-19 нехарактерний трахеобронхіт з яскравою запальною реакцією. Винятком є пацієнти, які перебували на штучній вентиляції легень із розвитком бактерійного трахеїту і бронхіту (Зайратьянц О.В. и соавт., 2020).

Втрату нюху (аносмія) та смаку (агезія) вважають характерними симптомами COVID-19. Хоча ці симптоми можуть виникати при будь-якій респіраторній інфекції внаслідок нежитю, той факт, що вони виникають у відриві від інших симптомів ураження слизової оболонки носоглотки, передбачає залучення до патологічного процесу нюхового нерва чи відповідних відділів центральної нервової системи (Ellul M.A. et al., 2020). Не можна виключити, що при COVID-19 може бути ураженим нервово-рецепторний апарат ШКТ, унаслідок чого симптоми з боку ШКТ можуть бути не маніфестними й субклінічними, незважаючи на тяжкість патологічних змін. Можливий парез кишечнику, навіть частковий, обтяжуватиме явища інтоксикації, аж до розвитку септичного стану.

Вивчення змін слизової оболонки ШКТ ускладнене на розтинах посмертним аутолізом, і характер патологічних змін ШКТ залишається досі недостатньо вивченим (Зайратьянц О.В. и соавт., 2020).

Мета - оцінити стан внутрішніх органів, дослідити стан слизової оболонки ШКТ померлих пацієнтів із COVID-19, виявити прижиттєві зміни слизової оболонки ШКТ й інтрамуральних нервових гангліїв у стінці кишечнику.

\section{Об"єкт і методи дослідження}

Матеріал для дослідження отриманий із патологоанатомічного відділення Комунального некомерційного підприємства «Міська клінічна лікарня № 21 імені професора Є.Г. Попкової» Дніпровської міської ради (Дніпро) від чотирьох померлих пацієнтів із COVID-19 (верифікованих методом полімеразної ланцюгової реакції), при розтині яких цілеспрямовано були взяті шматочки тканин із різних відділів кишкової трубки. Середній вік померлих $72 \pm 11$ року, середній термін перебування у стаціонарі $-11 \pm 10$ діб. У двох чоловіків віком 58 і 78 років діагностовано полісегментарну пневмонію тяжкої форми, смерть настала від легенево-серцевої недостатності. У жінки віком 71 рік діагностована інтерстиціальна пневмонія тяжкої форми, смерть настала від поліорганної недостатності. У трьох пацієнтів відзначали надмірну масу тіла. Виняток становив чоловік віком 83 роки з ознаками кахексії, гангреною лівої нижньої кінцівки, інсультом в анамнезі внаслідок атеросклерозу судин головного мозку, смерть якого не була безпосередньо пов'язана з COVID-19. Серед супутніх захворювань відзначено гіпертонічну хворобу, атеросклероз, цукровий діабет, жировий гепатоз. Вивчали гістологічні препарати внутрішніх органів, дванадцятипалої кишки, порожньої та ободової кишки, виготовлені за стандартною методикою, забарвлені гематоксиліном та еозином.

\section{Результати та їх обговорення}

У трьох померлих пацієнтів із COVID-19 виявили ураження легень у вигляді дифузного альвеолярного пошкодження, морфологічно схожого з картиною «шокових легень» при ГРДС. Відзначали інтраальвеолярний набряк із домішкою в набряковій 


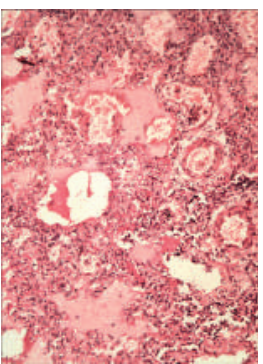

a

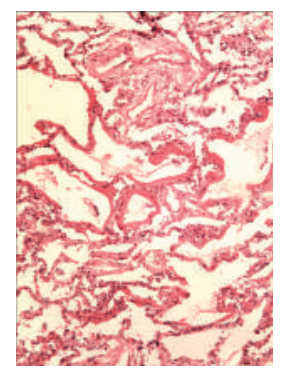

$\Gamma$

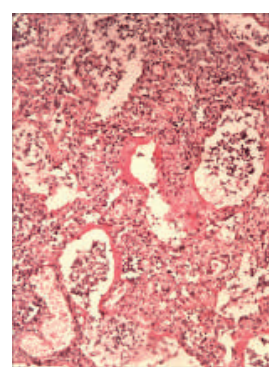

б

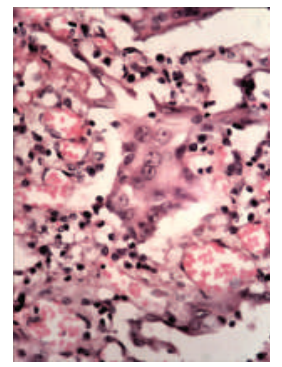

д

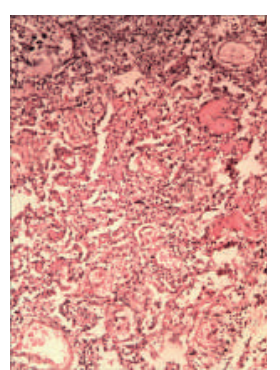

$B$

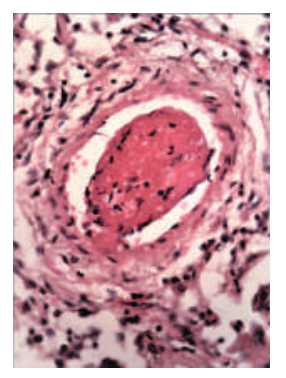

$\epsilon$

Рис. 1. Дифузне альвеолярне пошкодження, рання стадія: $a$ - інтраальвеолярний набряк, стази, діапедезні крововиливи, ×100, забарвлення гематоксиліном та еозином; б - те саме, десквамований альвеолярний епітелій, лімфоцити і макрофаги у просвітах альвеол, гіалінові мембрани, ×100, забарвлення гематоксиліном та еозином; в - те саме, фібринові та гіалінові тромби у просвіті дрібних судин, ×100, забарвлення гематоксиліном та еозином; $\Gamma$ - те саме, множинні гіалінові мембрани, що вистилають контури альвеол, $\times 100$, забарвлення гематоксиліном та еозином; д - те саме, цитопатичний (вірусасоційований) ефект: симпласт альвеолоцитів із великими ядрами у просвіті альвеоли, ×400, забарвлення гематоксиліном та еозином; $\epsilon$ - те саме, тромб у просвіті судини, $\times 400$, забарвлення гематоксиліном та еозином

рідині еритроцитів, лімфоцитів і макрофагів, відшарованого альвеолярного епітелію. По внутрішній поверхні альвеол спостерігали гіалінові мембрани різної товщини і поширеності (рис. 1 a, б, г). У капілярах міжальвеолярних перегородок, а також дрібних судинах відзначали фібринові та гіалінові тромби (рис. 1 в). Виявляли великі, неправильної форми альвеолоцити з великими ядрами, грубозернистим хроматином і вираженими ядерцями, що місцями формують симпласти (рис. 1 д). У деяких судинах середнього калібру спостерігали наявність тромбів (тромбоемболів?) (рис. $1 \epsilon$ ). Крововиливи мали характер діапедезних, гемосидероз був виражений мінімально. Ознаки фібропластичних реакцій були відсутні. Відзначали невідповідність стадій дифузного альвеолярного пошкодження тривалості захворювання. Так, зміни у легенях, характерні для ранньої ексудативної стадії, виявляли після 14 діб від початку захворювання за відсутності змін, характерних для пізньої проліферативної стадії.

У печінці виявляли жирову дистрофію різної вираженості, ознаки проміжного гепатиту, вогнища некрозу тканини печінки (рис. 2 а-б).

У нирках у всіх спостереженнях виявлені явища некротичного нефрозу з тотальним некрозом епітелію звитих канальців і фібриноїдний некроз капілярів клубочків (рис. 2 в).

У селезінці помічені фібриноїдні зміни строми, формування вогнищ некрозу і виражена дегенерація лімфоїдних елементів, аж до повного зникнення лімфоїдних фолікулів (рис. 2 г-д).

Вивчення змін слизової оболонки ШКТ показало широкий спектр уражень - від ознак гострого катарального запалення з початком зниження слизоутворення, десквамацією епітелію, формуванням поверхневих ерозій до наявності ділянок із глибоким ерозуванням слизової оболонки (рис. 3 а-г). Запальний інфільтрат був представлений лімфоцитами, макрофагами з домішкою плазмоцитів. Найбільш характерні зміни спостерігали в порожній кишці, де поряд із десквамативно-ерозійними явищами і ерозійно-некротичними пошкодженнями визначали ділянки пошкоджень підгострого характеру. Так, виявлено поля потовщених оголених ворсин з явною фібропластичною реакцією строми (рис. 4 а-б), деякі ворсини були спаяні одна з одною,

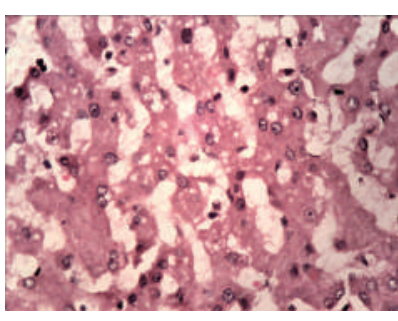

a

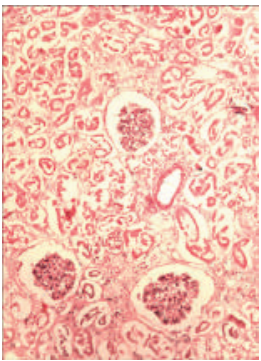

$B$

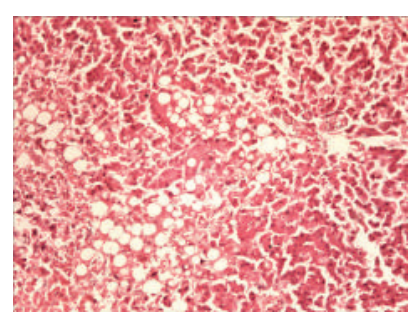

6

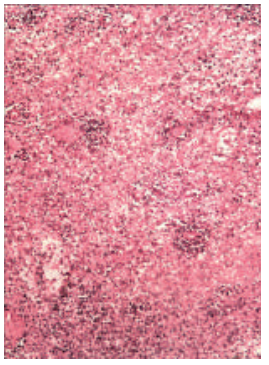

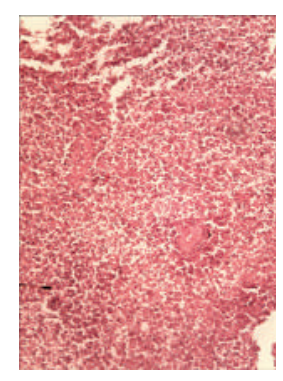

Д
Рис. 2. Зміни внутрішніх органів: а - печінка, дрібнокрапельна жирова дистрофія, ознаки проміжного гепатиту, $\times 400$, забарвлення гематоксиліном та еозином; б - те саме, великокрапельна жирова дистрофія, вогнища некрозу, ×100, забарвлення гематоксиліном та еозином; в- нирка, некроз епітелію звитих канальців і фібриноїдний некроз капілярів клубочків, ×100, забарвлення гематоксиліном та еозином, $\Gamma$ - селезінка, фібриноїдні зміни строми, дегенерація лімфоїдних елементів, $\times 100$, забарвлення гематоксиліном та еозином; д - те саме, зникнення лімфоїдних фолікулів, ×100, забарвлення гематоксиліном та еозином

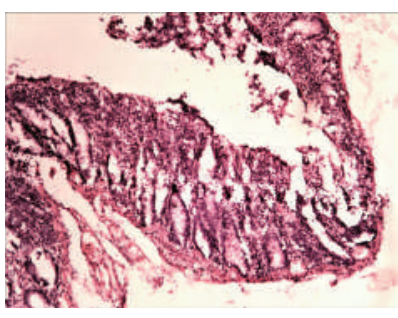

a

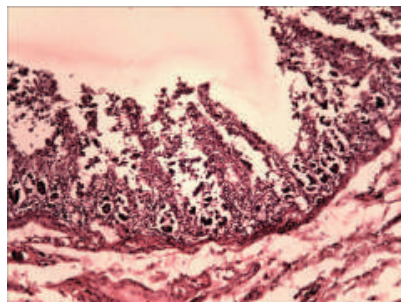

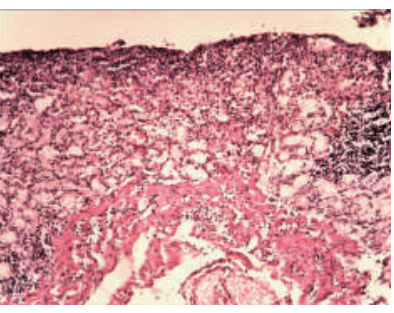

$\sigma$

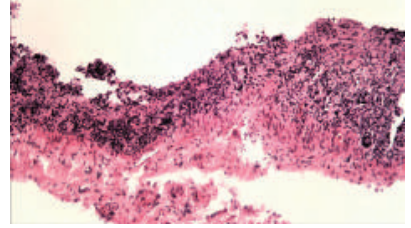

Рис. 3. Ураження слизової оболонки ШКТ: $a$ - товста кишка, катаральне запалення 3 початком зниження слизоутворення, десквамацією епітелію, формуванням поверхневих ерозій, ×100, забарвлення гематоксиліном та еозином; б - дванадцятипала кишка, гостра ерозія, повна відсутність ворсин, $\times 100$, забарвлення гематоксиліном та еозином, в - порожня кишка, гостре десквамативно-ерозійне ураження, $\times 100$, забарвлення гематоксиліном та еозином; $\ulcorner$ - те саме, гостре ерозійно-некротичне ураження з формуванням глибокої ерозії, ×40, забарвлення гематоксиліном та еозином

мали вигляд поліпоподібних виростів із частковою епітелізацією поверхні (рис. 4 в). Відзначали ділянки з ознаками епітелізації ерозованої поверхні слизової оболонки з тенденцією до вираженої атрофії (рис. 4 г).

При дослідженні стану інтрамуральних нервових гангліїв у стінці кишечнику виявлені нейродегенеративні явища. У разі незначної тривалості захворювання виявляли набухання тіл клітин, вакуолізацію цитоплазми, зсув ядра на периферію, хроматоліз, ішемічні зміни у вигляді наявності темних зморшкуватих нейронів. При більшій тривалості захворювання, окрім вищезазначених змін, мали місце каріоцитоліз і каріолізис із формуванням клітин-тіней. Нерідко спостерігали скупчення гліальних 


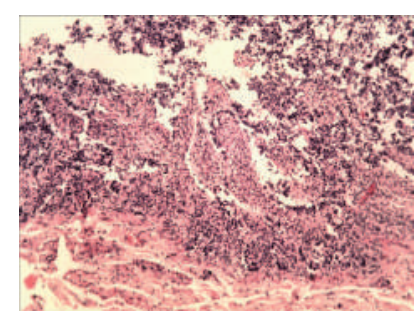

a

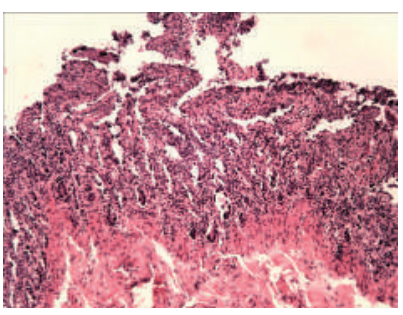

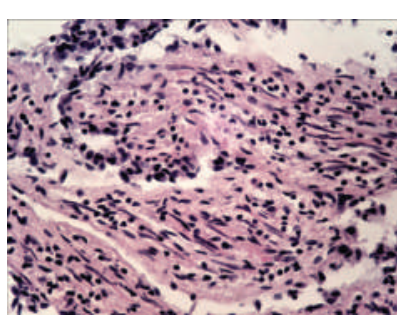

б

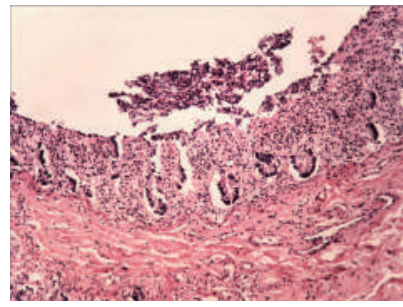

Рис. 4. Підгострі пошкодження слизової оболонки порожньої кишки: $a$ порожня кишка, поліпоподібно змінені ворсини з десквамативно-ерозійними явищами, $\times 40$, забарвлення гематоксиліном та еозином; б - те саме, велика кількість фібробластів у стромі потовщеної ворсини з частковою епітелізацією поверхні, ×400, забарвлення гематоксиліном та еозином, в - те саме, спайки між ворсинами, $\times 40$, забарвлення гематоксиліном та еозином, $\Gamma-$ те саме, епітелізація ерозованої поверхні атрофічної слизової оболонки, $\times 100$, забарвлення гематоксиліном та еозином

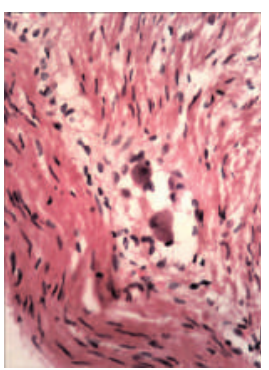

a

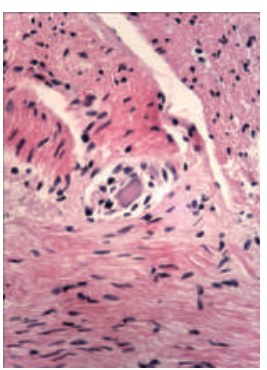

$B$

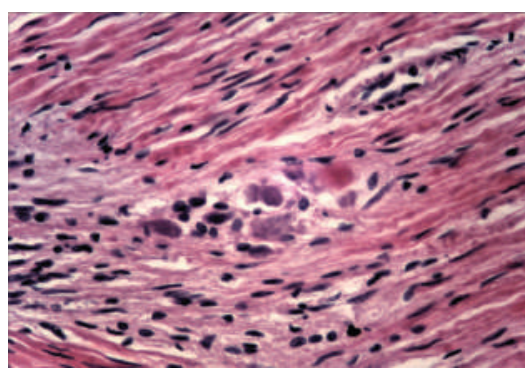

б

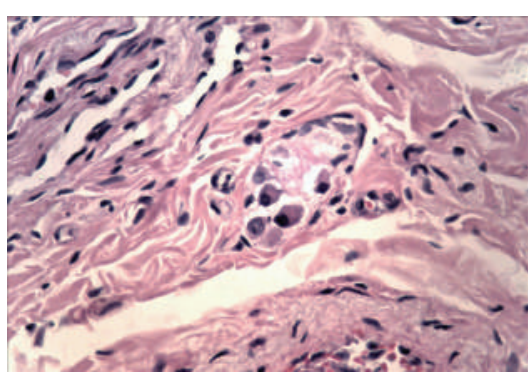

$\Gamma$ погіршувався на пізніх стадіях захворювання або у процесі одужання (Ye Q. et al., 2020). Така особливість виникнення тяжких ускладнень приводить до думки про те, що протягом захворювання відбувається непомітне накопичення вірусно-токсичного субстрату з раптовим проривом у кровоносну систему й подальшим розвитком так званого цитокінового шторму. Ймовірно, накопичувачем вірусно-токсичного субстрату може бути саме патологічно змінена тонка кишка, зокрема порожня кишка.

За наявності у пацієнтів вихідної гепатоцелюлярної та легенево-серцевої недостатності, що посилюється інтоксикацією внаслідок інфекційного процесу, може мати місце портальна гіпертензія із шунтуванням крові через венозні колатералі та пульмональна гіпертензія з артеріовенозним шунтуванням у малому колі кровообігу, що сприяє прямому потраплянню вірусу, токсинів і мікрофлори із ШКТ в мале і велике коло кровообігу (Krowka M.J. et al., 2000; Калачева Т.П. и соавт., 2009; Ахметзянова Э.Х. и соавт., 2010). Відповідно, можна вважати, що ГРДС та інші ускладнення при тяжкому COVID-19 є наслідком токсико-інфекційного шоку, зумовленого вірусним гастроентероколітом, приєднанням мікстінфекції за участю транзиторної та банальної умовно-патогенної мікрофлори. Явища шунтування крові можуть мати парціальний і транзиторний характер. Тоді добре пояснюється формування вогнищ полісегментарної пневмонії, яка може бути наслідком мікроемболій легеневої артерії з басейну системи комірної вени (Сухов М.Н. и соавт., 2010).

Той факт, що в печінці померлих пацієнтів із COVID-19 (>2000 аутопсій) увсіх спостереженнях виявлялижирову дистрофію різної вираженості, ознаки проміжного гепатиту, центролобулярні вогнища некрозу в частині випадків (Зайратьянц О.В. и соавт., 2020; Xu L. et al., 2020), дозволяє припускати наявність портальної гіпертензії у пацієнтів із COVID-19, а враховуючи те, що SARS-CoV-2 має високу тропність до епітелію ШКТ й активно в ньому реплікується, можна вважати, що ключовим чинником розвитку тяжких респіраторних розладів при COVID-19 є саме ураження ШКT.

На користь такого патогенезу COVID-19 свідчить систематичний огляд шлунково-кишкових проявів (Mao R. et al., 2020), згідно з яким наявність симптомів гастроентериту підвищує ризик розвитку тяжкого або критичного стану, а також ГРДС.

\section{Висновки}

COVID-19 є інфекцією не лише дихальних шляхів, але й ШКT.

Важливим чинником розвитку тяжкої і вкрай тяжкої форми COVID-19 може бути вірусно-бактеріальне ураження ШКТ, зокрема порожньої кишки, у поєднанні з захворюваннями, які спричиняють виникнення портопульмональної гіпертензії, що зумовлює пряме потрапляння вірусу, токсинів і мікрофлори з ШКТ в мале і велике коло кровообігу.

Необхідне подальше дослідження патологічних змін ШКТ, стану портальної венозної системи і портокавальних анастомозів при COVID-19.

Вважаємо раціональним враховувати істотну роль ураження ШКТ у розвитку хвороби, що сприятиме розробленню ефективних методів профілактики і лікування COVID-19, наприклад застосування діоктаедричного смектиту для зниження вірусного навантаження на ранніх стадіях захворювання з метою профілактики тяжкого перебігу захворювання.

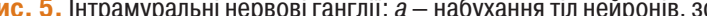
на периферію, ×400, забарвлення гематоксиліном та еозином; б- те саме темні зморщені нейрони, каріолізис, клітини-тіні, нейронофагія, $\times 400$, забарвлення гематоксиліном та еозином; в - те саме, хроматоліз і каріолізис $\times 400$, забарвлення гематоксиліном та еозином, $\Gamma-$ те саме, хроматоліз, вакуолізація цитоплазми, каріоцитоліз, ×400, забарвлення гематоксиліном та еозином

клітин поряд з дегенеруючими нейронами, що свідчило про нейронофагію (рис. 5 а-г).

Наявність у слизовій оболонці порожньої кишки пошкоджень підгострого характеру з фібропластичною реакцією строми може свідчити про раніше ураження порожньої кишки порівняно зі змінами у тканині легень. Виявлені в інтрамуральних нервових гангліях нейродегенеративні зміни свідчать про прогресуючий хвилеподібний перебіг захворювання, ймовірно, із безсимптомним характером.

Згідно з даними літератури, у більшості тяжкохворих та померлих пацієнтів не відзначали тяжких клінічних симптомів на ранній стадії захворювання на COVID-19. Стан цих пацієнтів раптово

\section{Список використаної літератури}

Ахметзянова Э.Х., Гайнитдинова В.В., Габдрахимова З.Г., Гареева Г.И. (2010) Легочная артериальная гипертензия и заболевания печени. Рос. кардиол. журн., 6: 61-63.

Зайратьянц О.В., Самсонова М.В., Михалева Л.М. и др. (2020) Патологическая анатомия COVID-19. НИИОЗММ ДЗМ, Москва, 140 с.

Калачева Т.П., Чернявская Г.М., Белобородова Э.И. (2009) Формирование легочной гипертензии у больных циррозом печени. Бюл. сиб. мед., 4: $45-48$.

Сухов М.Н., Белокриницкая И.Е., Собакинских Т.В. (2010) Внепеченочная портальная гипертензия у больных с кардиоваскулярной патологией. Детская больница, 2: 12-18.

Chan J.F., Yuan S., Kok K.H. et al. (2020) A familial cluster of pneumonia associated with the 2019 novel coronavirus indicating person-to-person transmission: a study of a family cluster. Lancet, 395: 514-523.

Ellul M.A., Benjamin L. , Singh B. et al. (2020) Neurological associations of COVID-19 The Lancet Neurol. Online ahead of print, July 2. doi:10.1016/ S14744422(20)30221-0. 
Krowka M.J., Wiseman G.A., Burnett O.L. et al. (2000) Hepatopulmonary syndrome: a prospective study of relationships between severity of liver disease, $\mathrm{PaO}_{2}$ response to $100 \%$ oxygen, and brain uptake after $(99 \mathrm{~m}) \mathrm{Tc}$ MAA lung scanning. Chest, 118: 615-624.

Mao R., Qiu Y., He J.-Sh. et al. (2020) Manifestations and prognosis of gastrointestinal and liver involvement in patients with COVID-19: a systematic review and meta-analysis. Lancet Gastroenterol. Hepatol. doi:10.1016/S24681253(20)30126-6.

Peiris J.S., Chu C.M., Cheng V.C. et al. (2003) Clinical progression and viral load in a community outbreak of coronavirus-associated SARS pneumonia: a prospective study. Lancet, 361: 1767-1772.

WHO (2020) Clinical care for severe acute respiratory infection: toolkit. COVID-19 adaptation (WH0/2019-nCoV/SARI_toolkit/2020.1).

Xu L. , Liu J., Lu M. et al. (2020) Liver injury during highly pathogenic human coronavirus infections. Liver Int., 40(5): 998-1004. doi: 10.1111/liv.14435.

Ye Q., Wang B., Mao J. et al. (2020) The pathogenesis and treatment of the «Cytokine Storm» in COVID-19. J. Infect., Apr. 10. doi: 10.1016/j.jinf.2020.03.037.

\section{Поражение тощей кишки как возможная причина развития острого респираторного дистресс-синдрома при COVID-19}

\section{К.В. Цыганков, В.А. Логвиненко, И.В. Кужевский, В.Н. Павленко}

Резюме. Актуальным и малоизученным вопросом при COVID-19 является морфологическая картина патологических изменений желудочно-кишечного тракта. На основании патоморфологического исследования материала от четырех умерших пациентов c COVID-19 и анализа данных литературы сделан вывод, что важным фактором развития тяжелой и крайне тяжелой формы COVID-19 может являться поражение тощей кишки в сочетании с заболевани- ями, обусловливающими возникновение портопульмональной гипертензии.

Ключевые слова: COVID-19, желудочно-кишечный тракт, тощая кишка, интрамуральный нервный ганглий, портопульмональная гипертензия.

\section{Damage of jejunum as a possible reason for the development of acute respiratory distress syndrome in COVID-19}

\section{K.V. Tsihankov, V.O. Logvinenko, I.V. Kuzhevsky, V.M. Pavlenko}

Summary. An actual and poorly studied question about COVID-19 is the morphological picture of pathological changes of the gastrointestinal tract. Based on the pathomorphological study of four deceased patients with COVID-19 and published data, it was concluded that an important factor in the development of severe and extreme severe cases of COVID-19 may also damage jejunum in combination with diseases that contribute to the development of portopulmonary hypertension.

Key words: COVID-19, gastrointestinal tract, jejunum, intramural nerve ganglion, portopulmonary hypertension.

\section{Адреса для листування:}

Циганков Костянтин Вікторович

49102, Дніпро, вул. Ближня, 31

Комунальне некомерційне підприємство

«Міська клінічна лікарня № 4»

Дніпровської міської ради,

відділення патологічної анатомії,

E-mail: 101262ts@gmail.com 